\title{
Thermoreversible mucoadhesive ophthalmic in situ hydrogel: Design and optimization using a combination of polymers
}

\author{
DIVYESH H. SHASTRI ${ }^{1+}$ \\ SHAILESH T. PRAJAPATI ${ }^{2}$ \\ LAXMANBHAI D. PATEL ${ }^{3}$ \\ 1 Department of Pharmaceutics \\ K. B. Institute of Pharmaceutical \\ Education and Research, Gandhinagar \\ Gujarat-382023, India \\ 2 Department of Pharmaceutics \\ Shri Sarvajanik Pharmacy College \\ Mehsana-384001, India \\ ${ }^{3}$ C. U. Shah College of Pharmacy and \\ Research, Wadhwan, Gujarat-363030 \\ India
}

Accepted August 2, 2010

\begin{abstract}
The purpose of the study was to develop an optimized thermoreversible in situ gelling ophthalmic drug delivery system based on Pluronic F 127, containing moxifloxacin hydrochloride as a model drug. A $3^{2}$ full factorial design was employed with two polymers: Pluronic F 68 and Gelrite as independent variables used in combination with Pluronic F 127. Gelation temperature, gel strength, bioadhesion force, viscosity and in vitro drug release after 1 and $10 \mathrm{~h}$ were selected as dependent variables. Pluronic F 68 loading with Pluronic F 127 was found to have a significant effect on gelation temperature of the formulation and to be of importance for gel formation at temperatures $33-36{ }^{\circ} \mathrm{C}$. Gelrite loading showed a positive effect on bioadhesion force and gel strength and was also found helpful in controling the release rate of the drug. The quadratic mathematical model developed is applicable to predicting formulations with desired gelation temperature, gel strength, bioadhesion force and drug release properties.
\end{abstract}

Keywords: moxifloxacin, in situ gel, ophthalmic drug delivery, mucoadhesive polymers, $3^{2}$ full factorial design

Nowadays, in situ gel forming systems are of great importance, having the combined advantage being patient convenient with favorable residence time for enhancing ocular bioavailability and for reducing systemic side effects $(1,2)$. The sol-gel transition can be induced by a shift in the $\mathrm{pH}$ (Carbomer) (3), temperature (poloxamer) or by the presence of deacetylated gellan gum cations (Gelrite) (4).

Poloxamer is a triblock copolymer made of polyethylene oxide (PEO) and polypropylene oxide (PPO) units. Formation of highly ordered structures such as cubic crystalline phase and intramolecular hydrogen bonds might promote gelation (6). The mucomimetic property of poloxamers is proposed to be due to their hydrophobic and hydrophilic sequences simulating mucin action by adsorption of the aqueous layer of tears on the hydrophobic epithelium. This makes them suitable for use as a drug delivery system.

\footnotetext{
* Correspondence; e-mail: divyeshshastri@gmail.com
} 
D. H. Shastri et al.: Thermoreversible mucoadhesive ophthalmic in situ hydrogel: Design and optimization using a combination of polymers, Acta Pharm. 60 (2010) 349-360.

Poloxamer 407 gives a colorless and transparent gel but requires higher concentration of about 25 to $30 \%(\mathrm{~m} / \mathrm{V})$ to exhibit sol-gel phase transition at $37^{\circ} \mathrm{C}$ when used alone (7). Gelation temperature can be adjusted within the range of $33-36{ }^{\circ} \mathrm{C}$ by modifying cross-linking agents (8), by mixing the different series of poloxamers (9), by changing the weight of poloxamers (10), or by changing the $\mathrm{pH}$ and ionic strength (11). However, studies have been focused on modulating only gelation temperatures of poloxamer solutions. There is lack of knowledge of the strength and bioadhesive force of gelled poloxamers.

In the present study, an attempt was made to solve this problem by combining two poloxamers, i.e., Pluronic F 127 (PF 127) and Pluronic F 68 (PF 68), and developing a series of combinations with gelation temperature ranging from 30 to $36{ }^{\circ} \mathrm{C}$ (12). They were found suitable for formulating an in situ gelling ophthalmic drug delivery system (IODDS) of moxifloxacin hydrochloride, a fourth-generation fluoroquinolone with enhanced activity against Gram-positive bacteria, including $S$. aureus (5).

PF $127(15 \%, m / V)$ was selected as the basis of formulation because below this concentration it loses its sol-gel transition properties (6). Optimization of PF 68 and Gelrite used in combination with PF 127 was done using a $3^{2}$ full factorial design. The effect of these polymers on gelation temperature, bioadhesion force, gel strength and in vitro release pattern of the drug was also studied.

\section{EXPERIMENTAL}

\section{Materials}

Moxifloxacin hydrochloride was obtained from the Torrent Research Centre (India), PF 127 (high molecular weight) and PF 68 (low molecular weight) were used as received from BASF India Ltd. (India), Gelrite was obtained from CP Kelco (Singapore). All other chemicals used were of analytical grade. Simulated tear fluid was freshly prepared and used $0.0238 \mathrm{~mol} \mathrm{~L}^{-1} \mathrm{NaHCO}_{3}, 0.1146 \mathrm{~mol} \mathrm{~L}^{-1} \mathrm{NaCl}$ and $0.0005 \mathrm{~mol} \mathrm{~L}^{-1} \mathrm{CaCl}_{2} \times 2 \mathrm{H}_{2} \mathrm{O}$ in water).

Instruments used were a UV visible spectrophotometer (UV-1800, Shimadzu, Japan), Brookfield viscometer (model LVT, Brookfield, USA), modified Franz diffusion cell (D. K. Scientific, India).

\section{Fabrication of in situ gel forming system of moxifloxacin hydrochloride}

The gel formulation was prepared aseptically using the cold method (7). The drug was accurately weighed and dissolved in sterile distilled deionized water and mixed with mucoadhesive polymer solution, i.e. Gelrite solution previously prepared by heating at $90{ }^{\circ} \mathrm{C}$ and cooled to room temperature (Table I). To this solution, required amounts of PF 127/PF 68 were added. All other excipients such as benzalkonium chloride $(0.001 \%, m / V)$, sodium chloride $0.5 \%(m / V)$, and disodium-EDTA $(0.001 \%, m / V)$, were added to the mixture. The volume was adjusted with sterile distilled deionized water to achieve a $0.5 \%(\mathrm{~m} / \mathrm{V})$ concentration of moxifloxacin hydrochloride. The solutions were adjusted to a $\mathrm{pH}$ in the range from 6.8 to 7.4 with $2 \mathrm{~mol} \mathrm{~L}^{-1} \mathrm{NaOH}$. The solu- 
D. H. Shastri et al.: Thermoreversible mucoadhesive ophthalmic in situ hydrogel: Design and optimization using a combination of polymers, Acta Pharm. 60 (2010) 349-360.

Table I. Composition of formulation batches

\begin{tabular}{cccccccccccc}
\hline $\begin{array}{c}\text { Formulation } \\
(\%, m / V)\end{array}$ & M1 & M2 & M3 & M4 & M5 & M6 & M7 & M8 & M9 & M10 & M11 \\
\hline MF.HCl & 0.5 & 0.5 & 0.5 & 0.5 & 0.5 & 0.5 & 0.5 & 0.5 & 0.5 & 0.5 & 0.5 \\
PF 127 & 15 & 15 & 15 & 15 & 15 & 15 & 15 & 15 & 15 & 15 & 15 \\
PF 68 & 14 & 14 & 14 & 15 & 15 & 15 & 16 & 16 & 16 & 14.5 & 15.5 \\
Gelrite & 0.3 & 0.5 & 0.7 & 0.3 & 0.5 & 0.7 & 0.3 & 0.5 & 0.7 & 0.6 & 0.4 \\
BKC & 0.001 & 0.001 & 0.001 & 0.001 & 0.001 & 0.001 & 0.001 & 0.001 & 0.001 & 0.001 & 0.001 \\
$\mathrm{Na}_{2}$-EDTA & 0.001 & 0.001 & 0.001 & 0.001 & 0.001 & 0.001 & 0.001 & 0.001 & 0.001 & 0.001 & 0.001 \\
NaCl & 0.5 & 0.5 & 0.5 & 0.5 & 0.5 & 0.5 & 0.5 & 0.5 & 0.5 & 0.5 & 0.5 \\
Sterile water & q.s. & q.s. & q.s. & q.s. & q.s. & q.s. & q.s. & q.s. & q.s. & q.s. & q.s. \\
\hline
\end{tabular}

$\mathrm{MF} \cdot \mathrm{HCl}$ - moxifloxacin hydrochloride, BKC - benzalkonium chloride

tions were mixed well and stored at $2-8{ }^{\circ} \mathrm{C}$ for $24 \mathrm{~h}$. Formulations were evaluated for clarity, consistency and spreadability.

\section{Characterization of gel formulations}

Gelation temperature. - Gels were evaluated for gelation temperature as described by Khan et al. (8) and Gilbert et al. (9). Gelation temperature was measured by heating the formulation in a 15- $\mathrm{mL}$ borosilicate glass test tube. Into each test tube, $2 \mathrm{~mL}$ of formulation solution was placed and heated with gentle stirring until the formulation solution got gelled. Gel formation was considered as the point where there was no flow when the test tubes were tilted more than $90^{\circ}$. All measurements were performed in triplicate $(n=3)$.

Content uniformity. - Formulations were tested for content uniformity. Vials $(n=3)$ containing the formulation were properly shaken for 2-3 min. One $\mathrm{mL}$ of the formulation was transferred into a $100-\mathrm{mL}$ volumetric flask. Fifty $\mathrm{mL}$ of simulated tear fluid $(\mathrm{pH}$ 7.4) was added. The formed gel was completely crushed with the help of a glass rod, followed by vigorous shaking until the formed gel got completely dispersed to give a clear solution (10). The volume was adjusted to $100 \mathrm{~mL}$ with simulated tear fluid. The solution was filtered through a $0.45-\mu \mathrm{m}$ filter membrane and the drug concentration was determined with a UV-Visible spectrophotometer at $291 \mathrm{~nm}$.

Bioadhesion force. - Gels were evaluated for bioadhesive force by the method described by Choi et al. (11). Excised sheep corneal membrane was immediately fixed with the mucosal side outwards onto a glass vial using a rubber band. Vials with the corneal membrane were stored at $37^{\circ} \mathrm{C}$ for $5 \mathrm{~min}$. Then, the next vial with a section of membrane was connected to a balance in an inverted position, while the first vial was placed on a height adjustable pan. The gel was placed onto the corneal membrane of the first vial. Then, the height of the second vial was adjusted so that the membrane surfaces of both vials came in close contact. A ten-minute contact time was chosen. The weight was 
D. H. Shastri et al.: Thermoreversible mucoadhesive ophthalmic in situ hydrogel: Design and optimization using a combination of polymers, Acta Pharm. 60 (2010) 349-360.

allowed to increase in the pan by adding water until the vials got detached. The bioadhesive force was measured as the minimum weight required for detaching two vials.

Gel strength. - Fifty mL of the gel sample was placed in a 100-mL graduated cylinder and gelled in a thermostat at $37^{\circ} \mathrm{C}$. The apparatus for measuring gel strength, as described by Choi et al. (11), was allowed to penetrate into the gel. Gel strength, i.e., the viscosity of the gel at physiological temperature, was determined by the time (in s) taken by the apparatus to sink $5 \mathrm{~cm}$ through the prepared gel. All measurements were performed in triplicate $(n=3)$.

Drug permeation. - A modified device (modified Franz diffusion cell using sheep cornea as a diffusion membrane) was used for evaluation of drug permeation. This membrane was tied to a specifically designed glass cylinder (open at both ends). Simulated tear fluid was used as the diffusion medium. The formulation to be tested was added to the donor chamber with the help of a micropipette. The donor surface of the membrane was constantly in contact with simulated tear fluid. Temperature of $37 \pm 0.5$ ${ }^{\circ} \mathrm{C}$ was maintained throughout the study. A magnetic stirrer provided continuous agitation. At regular time intervals, $5 \mathrm{~mL}$ of sample was withdrawn and replaced by fresh simulated tear fluid in order to maintain sink conditions. The samples were analyzed and absorbance was measured at $291 \mathrm{~nm}$ using a UV-VIS spectrophotometer. Cumulative percentage drug release after $1 \mathrm{~h}\left(t_{1}\right)$ and $10 \mathrm{~h}\left(t_{10}\right)$ were calculated using the Beer-Lambert calibration curve in the linearity range of $0-10 \mu \mathrm{g} \mathrm{mL}-1$.

Drug release data was fitted to different kinetic models like zero-order, first-order, Higuchi and Korsmeyer-Peppas (12). To find out the mechanism of drug release, $60 \%$ drug of release data was first fitted in the Korsmeyer-Peppas model equation (13):

$$
M_{t} / M_{\infty}=k t^{n}
$$

where, $M_{t} / M_{\infty}$ is fraction of drug released at time $t, k$ is the rate constant and $n$ is the release exponent. The magnitude of the release exponent $n$ indicates the release mechanism (i.e., Fickian diffusion, case II transport, or anomalous transport). In the present study, the limits considered were $n=0.45$ (indicates classical Fickian diffusion-controlled drug release) and $n=0.89$ (indicates a case II relaxational release transport, non-Fickian, zero-order release). Values of $n$ between 0.45 and 0.89 can be regarded as an indicator of both phenomena, commonly called anomalous transport or non-Fickian diffusion (14). Correlation was used as an indicator of the best fitting for each of the models considered (Table II).

Viscosity. - Viscosity of an instilled formulation is an important factor in determining the residence time of drug in the eye. The formulations were poured into the sample adaptor of the Brookfield viscometer and angular velocity was increased gradually from 0.3 to $60 \mathrm{rpm}$. The hierarchy of angular velocity was reversed and the average dial reading was considered to calculate the viscosity (3). The temperature was maintained within $37 \pm 0.1^{\circ} \mathrm{C}$ by a recirculating bath connected to the sample cup of the viscometer. The samples were equilibrated on the plate for $5 \mathrm{~min}$ to reach the running temperature before each measurement. 
D. H. Shastri et al.: Thermoreversible mucoadhesive ophthalmic in situ hydrogel: Design and optimization using a combination of polymers, Acta Pharm. 60 (2010) 349-360.

\section{Formulation design}

A $3^{2}$ full factorial design was used in the study, in which two factors were evaluated and experimental trials were performed with all 9 possible combinations. The concentrations of PF68 as $X_{1}(14,15$ and $16 \%, m / V)$ and Gelrite (cation sensitive in situ gelling, hydrophilic and mucoadhesive polymer) as $X_{2}(0.3,0.5$ and $0.7 \%, \mathrm{~m} / \mathrm{V})$ were selected as independent variables. Gelation temperature (GT in ${ }^{\circ} \mathrm{C}$ ), gel strength (GS in s), bioadhesion force (BF in $\mathrm{N}$ ), viscosity ( $\eta$ in Pa s) and cumulative percent drug release after 1 and $10 \mathrm{~h}\left(t_{1}\right.$ and $t_{10}$, respectively) were selected as dependent variables. The experimental design is outlined in Table III. DESIGN EXPERT 7.0.11 (STAT-EASE) demo version software was used for the formulation design. In this design, there are 2 independent variables and 3 levels (low, medium, and high) of each variable:

$$
Y=b_{0}+b_{1} X_{1}+b_{2} X_{2}+b_{11} X_{11}+b_{22} X_{22}+b_{12} X_{1} X_{2}
$$

where $Y$ is the dependent variable, $b_{0}$ is the mean response of the 9 runs, and $b_{\mathrm{i}}$ is the estimated coefficient for factor $X_{\mathrm{i}}$. The main effects $\left(X_{1}\right.$ and $\left.X_{2}\right)$ represent the average result of changing a factor at a time from its low to high value. The interaction term $\left(X_{12}\right)$ shows how the response changes when the factors are simultaneously changed. Polynomial terms $\left(X_{11}\right.$ and $\left.X_{22}\right)$ are included to investigate nonlinearity.

\section{Statistical analysis}

Statistical analysis of the factorial design batches was performed by multiple regression analysis using Microsoft Excel ${ }^{\circledR}$. To evaluate the contribution of each factor with different levels to the response, the two-way analysis of variance (ANOVA) was perfor-

Table II. Model fitting of drug release data

\begin{tabular}{|c|c|c|c|c|c|c|}
\hline \multirow[t]{2}{*}{ Batch code } & \multirow[t]{2}{*}{ Higuchi } & \multirow{2}{*}{$\begin{array}{c}\text { Zero } \\
R^{2}\end{array}$} & \multirow[t]{2}{*}{ First } & \multicolumn{3}{|c|}{ Korsmeyer-Peppas } \\
\hline & & & & $R^{2}$ & $k\left(\mathrm{~h}^{-n}\right)$ & $n$ \\
\hline M1 & 0.9969 & 0.9922 & 0.9714 & 0.9952 & 0.2393 & 0.4400 \\
\hline M2 & 0.9972 & 0.9885 & 0.9609 & 0.9945 & 0.2189 & 0.4669 \\
\hline M3 & 0.9938 & 0.9968 & 0.9756 & 0.9891 & 0.1828 & 0.5097 \\
\hline M4 & 0.9965 & 0.9920 & 0.9660 & 0.9936 & 0.1971 & 0.4860 \\
\hline M5 & 0.9946 & 0.9975 & 0.9771 & 0.9914 & 0.1968 & 0.4731 \\
\hline M6 & 0.9867 & 0.9988 & 0.9835 & 0.9867 & 0.1535 & 0.5500 \\
\hline M7 & 0.9992 & 0.9859 & 0.9431 & 0.9993 & 0.1978 & 0.5136 \\
\hline M8 & 0.9863 & 0.9981 & 0.9815 & 0.9884 & 0.1683 & 0.5225 \\
\hline M9 & 0.9817 & 0.9977 & 0.9845 & 0.9837 & 0.1282 & 0.5917 \\
\hline M10a & 0.9903 & 0.9990 & 0.9851 & 0.9864 & 0.1896 & 0.4396 \\
\hline${\mathrm{M} 11^{\mathrm{a}}}$ & 0.9985 & 0.9916 & 0.9651 & 0.9957 & 0.2167 & 0.4325 \\
\hline
\end{tabular}

a Indicates check point batches. 
D. H. Shastri et al.: Thermoreversible mucoadhesive ophthalmic in situ hydrogel: Design and optimization using a combination of polymers, Acta Pharm. 60 (2010) 349-360.

Table III. Formulation and drug release characteristics of all batches in a $3^{2}$ full factorial design

\begin{tabular}{|c|c|c|c|c|c|c|c|c|}
\hline $\begin{array}{l}\text { Batch } \\
\text { code }\end{array}$ & $\begin{array}{c}\text { PF68 } \\
X_{1}\end{array}$ & $\begin{array}{c}\text { Gelrite } \\
X_{2}\end{array}$ & $\begin{array}{l}\text { GT } \\
\left({ }^{\circ} \mathrm{C}\right)\end{array}$ & $\begin{array}{l}\text { GS } \\
\text { (s) }\end{array}$ & $\begin{array}{c}\mathrm{BF} \times 10^{5} \\
(\mathrm{~N})\end{array}$ & $\begin{array}{l}t_{1} \\
(\%)\end{array}$ & $\begin{array}{l}t_{10} \\
(\%)\end{array}$ & $\begin{array}{l}\eta \times 10 \\
(\text { Pa s) }\end{array}$ \\
\hline M1 & -1 & -1 & $39.67 \pm 0.76$ & $135.33 \pm 1.53$ & $2255.61 \pm 98.07$ & 24.8 & 66.2 & 2948 \\
\hline M2 & -1 & 0 & $38.16 \pm 0.76$ & $140.33 \pm 1.53$ & $3040.17 \pm 98.07$ & 21.5 & 61.3 & 3620 \\
\hline M3 & -1 & +1 & $37.50 \pm 0.50$ & $148.00 \pm 2.52$ & $4903.50 \pm 98.07$ & 19.6 & 64.7 & 3975 \\
\hline M4 & 0 & -1 & $34.84 \pm 0.76$ & $138.33 \pm 2.52$ & $2222.92 \pm 149.8$ & 23.6 & 65.4 & 3910 \\
\hline M5 & 0 & 0 & $34.00 \pm 0.50$ & $146.00 \pm 2.00$ & $3269.61 \pm 56.62$ & 21.6 & 60.2 & 4465 \\
\hline M6 & 0 & +1 & $32.84 \pm 3.05$ & $152.00 \pm 3.05$ & $5001.57 \pm 98.07$ & 18.2 & 58.7 & 4896 \\
\hline M7 & +1 & -1 & $31.50 \pm 0.50$ & $147.33 \pm 2.08$ & $2320.99 \pm 56.62$ & 20.7 & 60.3 & 4157 \\
\hline M8 & +1 & 0 & $29.50 \pm 0.50$ & $155.67 \pm 1.15$ & $3432.45 \pm 98.07$ & 17.2 & 57.4 & 4635 \\
\hline M9 & +1 & +1 & $26.84 \pm 0.29$ & $164.34 \pm 2.52$ & $5132.33 \pm 149.8$ & 14.5 & 52.0 & 5115 \\
\hline M10 & -0.5 & +0.5 & $38.00 \pm 0.50$ & $144.67 \pm 3.05$ & $4478.53 \pm 56.62$ & 20.8 & 53.9 & 3200 \\
\hline \multirow[t]{4}{*}{ M11 $^{\mathrm{a}}$} & +0.5 & -0.5 & $35.00 \pm 0.50$ & $140.00 \pm 3.00$ & $2811.34 \pm 56.62$ & 23.2 & 58.5 & 4100 \\
\hline & Level & Low $(-1)$ & Medium (0) & High $(+1)$ & & & & \\
\hline & $X_{1}(\%)$ & 14 & 15 & 16 & & & & \\
\hline & $X_{2}(\%)$ & 0.3 & 0.5 & 0.7 & & & & \\
\hline
\end{tabular}

GT - gelation temperature, GS - gel strength, BF - bioadhesion force, $t_{1}$ - cumulative percent drug release after $1 \mathrm{~h}, t_{10}$ - cumulative percent drug after $10 \mathrm{~h}, \eta$ - viscosity at $37^{\circ} \mathrm{C}$.

a Indicates check point batch.

med. To graphically demonstrate the influence of each factor on the response, the response surface plots were generated with the help of design expert software.

\section{RESULTS AND DISCUSSION}

Preliminary investigations of the process parameters revealed that factors $X_{1}(\%$, $m / V$, of PF 68) and $X_{2}(\%, m / V$ of Gelrite) highly influenced the rate of in vitro drug release and hence, they were used for further systematic studies. In the present investigation, combinations of two polymers were studied using a $3^{2}$ full factorial design. Mathematical models developed for all the dependent variables using statistical analysis software are shown in Eqs. (3) - (8):

$$
\begin{aligned}
& \mathrm{GT}=33.90778-4.58167^{*} \mathrm{X} 1-1.47167^{*} \mathrm{X} 2-0.03167^{*} \mathrm{X} 1^{\wedge} 2-0.02167^{*} \mathrm{X} 2^{\wedge} 2-0.6225^{*} \mathrm{X} 1^{*} \mathrm{X} 2 \\
& R=0.9969
\end{aligned}
$$

GS $=145.2956+7.28^{*} X 1+7.225^{*} X 2+3.056667^{*} X 1^{\wedge} 2+0.221667^{*} X 2^{\wedge} 2+1.085^{*} X 1^{*} X 2$

$R=0.9985$ 
D. H. Shastri et al:: Thermoreversible mucoadhesive ophthalmic in situ hydrogel: Design and optimization using a combination of polymers, Acta Pharm. 60 (2010) 349-360.

$$
\begin{aligned}
& \mathrm{BF}=3236.649+114.415^{*} \mathrm{X} 1+1372.98^{*} \mathrm{X} 2+16.14167^{*} X 1^{\wedge} 2+392.0767^{*} X 2^{\wedge} 2+40.8625^{*} X 1^{*} X 2 \\
& R=0.9990
\end{aligned}
$$

$t_{1}=21.06103-2.25634^{*} X 1-2.79291^{*} X 2-1.40333^{*} X 1^{\wedge} 2+0.123824^{*} X 2^{\wedge} 2-0.24765^{*} X 1^{*} X 2$

$R=0.9954$

$t_{10}=60.35441-3.74223^{*} X 1-2.75164^{*} X 2-1.07314^{*} X 1^{\wedge} 2+1.568433^{*} X 2^{\wedge} 2-1.71289^{*} X 1^{*} X 2$

$R=0.9652$

$\eta=4472.4444+560.66667^{*} \mathrm{X} 1+495.166667^{*} \mathrm{X} 2-348.666667^{*} \mathrm{X} 1^{\wedge} 2-73.1666667^{*} \mathrm{X} 2^{\wedge} 2-$

$17.25^{*} X 1 * X 2$

$R=0.9988$

Lower value of the correlation coefficient, $R$ (Eq. 7) indicated that all formulations had drug release after $10 \mathrm{~h}$ below $70 \%(\mathrm{~m} / \mathrm{V})$, with insignificant effect of the concentration of polymers (Table IV). This was due to the formation of a strong polymer gel network and entrapment of the drug inside hydrated polymeric matrices, resulting in sustained release of the drug after $10 \mathrm{~h}$. Gelation temperature, gel strength and bioadhesion force showed wide variations (Table III). The data clearly indicate that the dependent variables GT, GS and BF, are strongly dependent on the independent variables. Correlation coefficients indicate a good fit. The polynomial equation can be used to draw a conclusion after considering the magnitude of the coefficient and the mathematical sign it carries (positive or negative).

To demonstrate graphically the effect of the amount of PF68 and Gelrite, response surface plots were generated for the dependent variables GT, GS, BF and viscosity (Fig. 1).

Results of ANOVA for the measured responses are provided in Table IV. It was found that the amount of PF68 had a significant effect on gelation temperature of the system $(p<0.05)$, while Gelrite had a significant effect on bioadhesion force, gel strength and $t_{1}(p<0.05)$.

As the amount of PF 68 and Gelrite increased, gel strength increased as well; this must be due to the additional effect of the concentration of both polymers. As Gelrite concentration increased, the bioadhesion force also increased. However, BF was less affected by the increase of PF 68 concentration than that of Gelrite. This may be due to the interaction of gellan gum with the mucin of the cul-de-sac. Increased viscosity due to formation of a denser polymeric network between the long polyoxyethylene-polyoxypropylene-polyoxyethylene chains of poloxamers with the gellan gum resulted in increased gel strength of the formulation.

In vitro drug release profiles of the formulations are compared in Fig. 2. To confirm the diffusion mechanism, the data were fitted into the Korsmeyer-Peppas equation.

Although the type of polymer and its concentration had a significant influence on gelation temperature, gel strength, bioadhesion force and $t_{1}$, the diffusion exponent $(n)$ values showed that diffusion was the predominant mechanism of drug release from these formulations ( $R^{2}$ of 0.9993$)$, with slope $(n)$ ranging from 0.432 to 0.591 appears to indi- 
D. H. Shastri et al.: Thermoreversible mucoadhesive ophthalmic in situ hydrogel: Design and optimization using a combination of polymers, Acta Pharm. 60 (2010) 349-360.
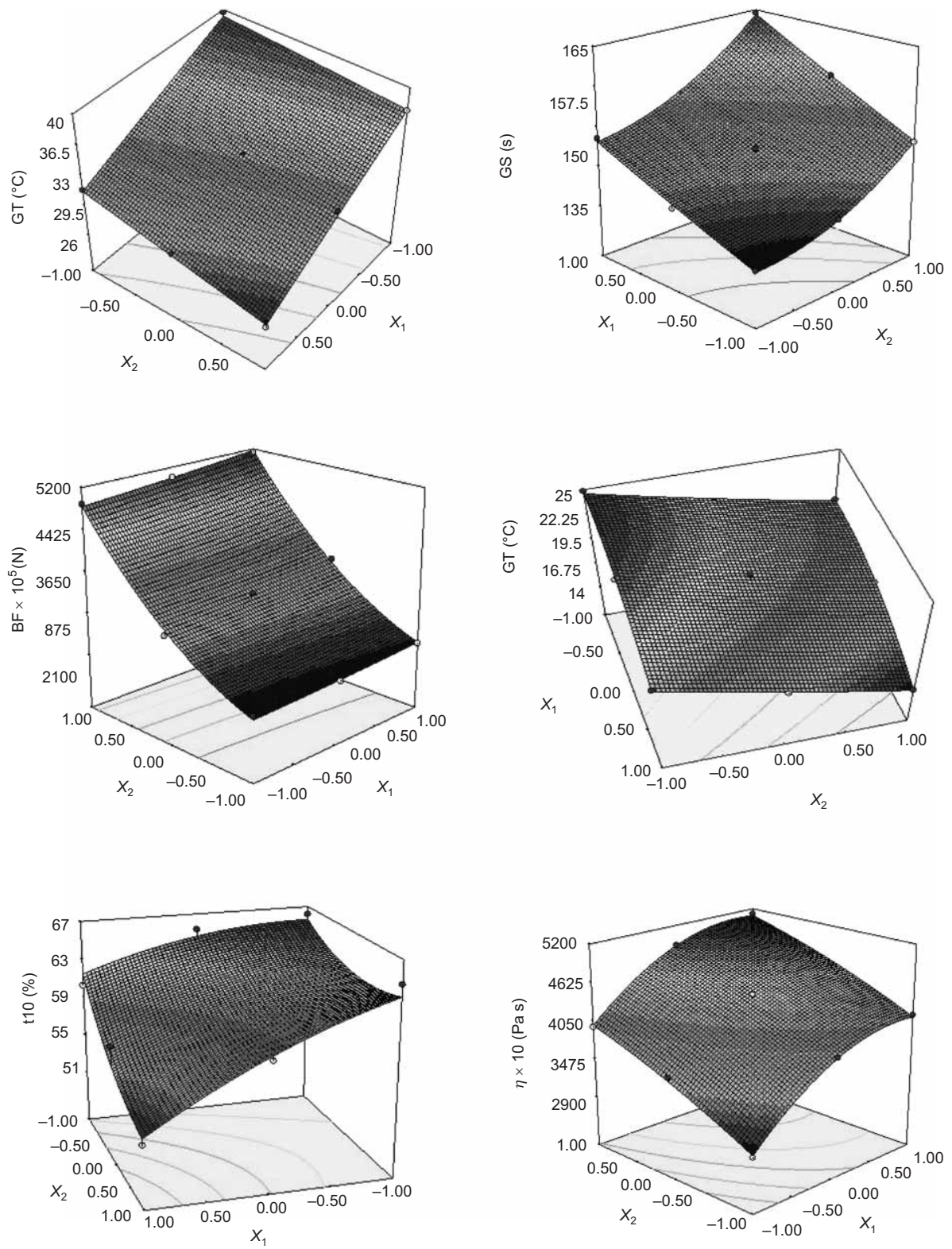

Fig. 1. Response surface plot for effects of the amount of PF 68 and Gelrite on: a) gelation temperature (GT) $\left.\left({ }^{\circ} \mathrm{C}\right), \mathrm{b}\right)$ gel strength (GS) $(\mathrm{s})$, c) bioadhesion force $\left(\mathrm{BF} \times 10^{5}, \mathrm{~N}\right)$, d) viscosity $(\eta \times 10$, Pa s), e) cumulative percentage drug release after $1 \mathrm{~h}\left(t_{1}\right)(\%)$, f) cumulative percentage drug release after $10 \mathrm{~h}\left(t_{10}\right)(\%)$.

$X_{1}$ - concentration of PF68 $(\%, m / V)$

$X_{2}$ - concentration of Gelrite $(\%, m / V)$ 
D. H. Shastri et al.: Thermoreversible mucoadhesive ophthalmic in situ hydrogel: Design and optimization using a combination of polymers, Acta Pharm. 60 (2010) 349-360.

cate anomalous drug release involving a combination of Fickian and non-Fickian diffusion. This might be due to entrapment of the drug moxifloxacin $\cdot \mathrm{HCl}$ into polymer matrices as well as to the difference in characteristics of polymers. Non-linear relationship was obtained between the diffusion exponent and two independent variables. It was observed that as the concentration of Gelrite increased, the diffusion exponent increased to an intermediate value and then decreased.

Checkpoint batches M10 and M11 were prepared (Table I) at $X_{1}=-0.5$ and 0.5 and $X_{2}=0.5$ and -0.5 levels, respectively. The actual values of GT $\left({ }^{\circ} \mathrm{C}\right), \mathrm{GS}(\mathrm{s}), \mathrm{BF}(\mathrm{kN})$, viscosity (Pa s) and $t_{1}(\%)$ of batches M10 and M11 are given in (Table V). For the check

Table IV. Analysis of variance for dependent variables of the $3^{2}$ full factorial design

\begin{tabular}{|c|c|c|c|c|c|c|}
\hline Source & $\mathrm{df}$ & SS & MS & F-value & $R^{2}$ & $p$ \\
\hline \multicolumn{7}{|c|}{ Gelation temperature $\left({ }^{\circ} \mathrm{C}\right)$} \\
\hline Regression & 5 & 140.4978 & 28.0996 & 96.17 & 0.9938 & 0.0016 \\
\hline Residual & 3 & 0.8766 & 0.2922 & & & \\
\hline Total & 8 & 141.3744 & & & & \\
\hline \multicolumn{7}{|c|}{ Gel strength (s) } \\
\hline Regression & 5 & 654.6877 & 130.9375 & 193.58 & 0.9969 & 0.0006 \\
\hline Residual & 3 & 2.0291 & 0.6764 & & & \\
\hline Total & 8 & 656.7169 & & & & \\
\hline \multicolumn{7}{|c|}{ Bioadhesion force $\times 10^{5}(\mathrm{~N})$} \\
\hline Regression & 5 & 11703637.54 & 2340727.51 & 301.60 & 0.9980 & 0.0003 \\
\hline Residual & 3 & 23282.88 & 7760.96 & & & \\
\hline Total & 8 & 11726920.43 & & & & \\
\hline \multicolumn{7}{|c|}{ Viscosity $\times 10(\mathrm{~Pa} \mathrm{~s})$} \\
\hline Regression & 5 & 81.563 & 16.313 & 64.89 & 0.9976 & 0.0029 \\
\hline Residual & 3 & 0.754 & 0.251 & & & \\
\hline Total & 8 & 82.317 & & & & \\
\hline \multicolumn{7}{|l|}{$t_{1}(\%)$} \\
\hline Regression & 5 & 3612256.694 & 722451.339 & 251.47 & 0.9908 & 0.0004 \\
\hline Residual & 3 & 8618.861 & 2872.954 & & & \\
\hline Total & 8 & 3620875.556 & & & & \\
\hline \multicolumn{7}{|l|}{$t_{10}(\%)$} \\
\hline Regression & 5 & 148.414 & 29.683 & 8.19 & 0.9317 & 0.0569 \\
\hline Residual & 3 & 10.879 & 3.626 & & & \\
\hline Total & 8 & 159.292 & & & & \\
\hline
\end{tabular}

SS - sum of squares, df - degree of freedom, MS - mean square, F - Fischer's ratio, $p$ - significance level, $t_{1}$ - cumulative percentage drug release after $1 \mathrm{~h}, t_{10}$ - cumulative percentage drug release after $10 \mathrm{~h}$ 
D. H. Shastri et al:: Thermoreversible mucoadhesive ophthalmic in situ hydrogel: Design and optimization using a combination of polymers, Acta Pharm. 60 (2010) 349-360.

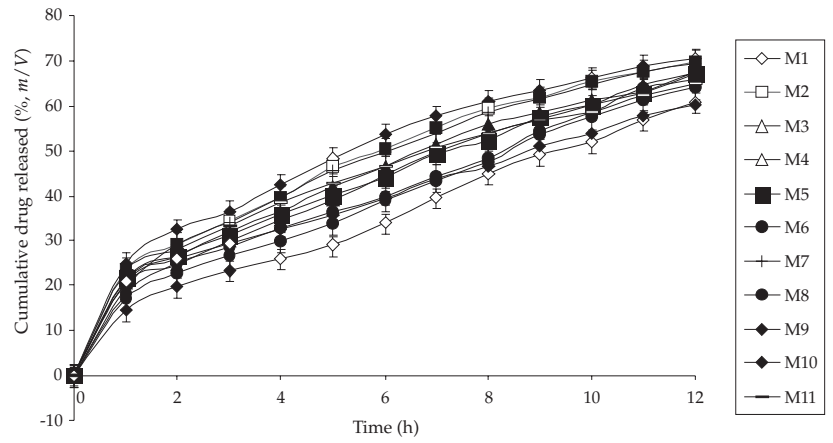

Fig. 2. Cumulative drug release of developed formulations. Mean $\pm \mathrm{SD}, n=3$.

point batch M11, the predicted values of $32.49,145.87,2.70,4.40$ and 21.1, respectively, are in good agreement with the actual values of $35,140,2.81,4.10$ and 23.2, respectively. Similarly, the predicted values of batch M10 were also in good agreement with the actual values.

Table V. Comparison of the actual value with predicted values of check point batches

\begin{tabular}{ccccccccc}
\hline \multicolumn{7}{c}{ Actual values } \\
\hline Batch code & PF68 & Gelrite & GT $\left({ }^{\circ} \mathrm{C}\right)$ & GS $(\mathrm{s})$ & BF $\times 10^{5}(\mathrm{~N})$ & $t_{1}(\%)$ & $t_{10}(\%)$ & $\eta \times 10(\mathrm{~Pa} \mathrm{~s})$ \\
\hline M10 & -0.5 & +0.5 & 38 & 144.67 & 4478.53 & 20.79 & 53.89 & 3200 \\
M11 & +0.5 & -0.5 & 35 & 140 & 2811.34 & 23.18 & 58.51 & 4100 \\
\hline \multicolumn{7}{c}{ Predicted values } \\
\hline Batch code & PF68 & G & GT $\left({ }^{\circ} \mathrm{C}\right)$ & GS $(\mathrm{s})$ & BF $\times 10^{5}(\mathrm{~N})$ & $t_{1}(\%)$ & $t_{10}(\%)$ & $\eta \times 10(\mathrm{~Pa} \mathrm{~s})$ \\
\hline M10 & -0.5 & +0.5 & 35.60 & 145.81 & 3957.77 & 20.53 & 61.40 & 4338 \\
M11 & +0.5 & -0.5 & 32.49 & 145.87 & 2699.20 & 21.07 & 60.41 & 4404 \\
\hline
\end{tabular}

GT - gelation temperature, GS - gel strength, BF - bioadhesion force, $t_{1}$ - cumulative percentage of drug release after $1 \mathrm{~h}, t_{10}$ - cumulative percentage of drug release after $10 \mathrm{~h}, \eta$ - viscosity at $37^{\circ} \mathrm{C}$

\section{CONCLUSIONS}

When poloxamers were used in combination for developing IODDS, low to moderate amounts of Gelrite and PF 68 were to be used to achieve the desired gelation temperature, gel strength, mucoadhesion, drug release profile and viscosity required for a sustained ophthalmic drug delivery system of moxifloxacin hydrochloride. It was concluded that the amounts of Gelrite had a significant effect on bioadhesion force and gel strength of the formulated IODDS. The quadratic mathematical model developed is applicable to predicting ophthalmic in situ gel formulations with desired characteristics. 
D. H. Shastri et al:: Thermoreversible mucoadhesive ophthalmic in situ hydrogel: Design and optimization using a combination of polymers, Acta Pharm. 60 (2010) 349-360.

Acknowledgments. - The authors are grateful to Suvik Pharma (Gandhinagar, India) for providing facilities for this research work and to the Torrent Research Centre, Gandhinagar, for the gift sample of moxifloxacin hydrochloride and BASF India Ltd., CP Kelco, India, for providing PF 127, PF 68 and Gelrite.

\section{REFERENCES}

1. A. K. Mitra, Ophthalmic Drug Delivery System, Vol. 58, Marcel Dekker, New York 1993, pp. 105-110.

2. A. G. Kaur, P. Indu, K. S. Anil and A. Deepika Vesicular systems in ocular drug delivery. An overview, Int. J. Pharm. 269 (2004) 1-14; DOI: 10.1016/j.ijpharm.2003.09.016.

3. C. L. Bourlais, L. Acar, H. Zia, P. A. Sado, T. Needham and R. Leverge, Ophthalmic drug delivery systems - recent advances, Prog. Retin. Eye Res. 77 (1998) 33-58.

4. M. Paulsson, H. Hagerstrom and K. Edsman, Rheological studies of the gelation of deacetylated gellan gum (Gelrite) in physiological conditions, Eur. J. Pharm. Sci. 9 (1999) 99-105; DOI: 10.1016/ S0928-0987(99)00051-2.

5. D. J. Biedenbach and R. N. Jones, The comparative antimicrobial activity of levofloxacin tested against 350 clinical isolates of Streptococci, Diagn. Microbiol. Infect. Dis. 25 (1996) 47-51; DOI: 10.1016/0732-8893(96)00066-1.

6. K. Edsman, J. Carlfors and R. Peterson, Rheological evaluation of Poloxamer as in situ gel for ophthalmic use, Eur. J. Pharm. Sci. 6 (1998) 105-112; DOI: 10.1016/S0928-0987(97)00075-4.

7. I. R. Schmolka. A review of block polymer surfactants, J. Am. Oil Chem. Soc. 54 (1977) 110-116; DOI: $10.1007 /$ BF02894385.

8. S. Khan, D. S. Singhara and P. G. Yeole, Temperature induced in situ gel of lidocaine hydrochloride for periodontal anesthesia, Indian Drugs 42 (2005) 519-524.

9. J. C. Gilbert, J. L. Richardson, M. C. Davies, K. J. Palin and J. Hadgraft, The effect of solutes and polymers on the gelation properties of Pluronic F127 solutions for controlled drug delivery, J. Control. Rel. 5 (1987) 113-118; DOI: 10.1016/0168-3659(87)90002-2.

10. J. Balasubramaniam, S. Kant and J. K. Pandit, In vitro and in vivo evaluation of Gelrite ${ }^{\circledR}$ gellan gum based ocular delivery system of indomethacin, Acta Pharm. 53 (2003) 251-261.

11. H. G. Choi, J. H. Jung, J. M. Ryu, S. J. Yoon, Y. K. Oh and C. K. Kim, Development of in situ-gelling and mucoadhesive acetaminophen liquid suppository, Int. J. Pharm. 165 (1998) 33-44; DOI: 10.1016/S0378-5173(97)00386-4.

12. C. Puglia, F. Bonina, G. Trapani, M. Franco and M. Ricci, Evaluation of in vitro percutaneous absorption of lorazepam and clonazepam from hydro-alcoholic gel formulations, Int. J. Pharm. 228 (2001) 79-87; DOI: 10.1016/S0378-5173(01)0806-7.

13. R. W. Korsmeyer, R. Gurny, E. Doelker, P. Buri and N. A. Peppas, Mechanisms of solute release from porous hydrophilic polymers, Int. J. Pharm. 15 (1983) 25-35.

14. P. Costa and J. M. S. Lobo, Modeling and comparison of dissolution profiles. Eur. J. Pharm. Sci. 13 (2001) 123-133; DOI: 10.1016/S0928-0987(01)00095-1. 
D. H. Shastri et al.: Thermoreversible mucoadhesive ophthalmic in situ hydrogel: Design and optimization using a combination of polymers, Acta Pharm. 60 (2010) 349-360.

\author{
$S A \check{Z} E T A K$
}

\title{
Termoreverzibilni mukoadhezivni in situ hidrogel za oftalmičku primjenu: Dizajniranje i optimizacija koristeći kombinaciju polimera
}

DIVYESH H. SHASTRI, SHAILESH T. PRAJAPATI i LAXMANBHAI D. PATEL

Cilj rada bio je razvoj i optimizacija termoreverzibilnog sustava za isporuku lijekova koji gelira in situ. Sustav je napravljen na bazi Pluronic F 127, a sadrži moksifloksacin hidroklorid kao modelni lijek. U radu je primjenjeno $3^{2}$ potpuno faktorijsko dizajniranje s dva polimera, Pluronic F 68 i Gelrite kao nezavisnim varijablama koji su kombinirani s Pluronic F 127. Kao zavisne varijable odabrane su temperatura geliranja, čvrstoća gela, jačina bioadhezije, viskoznost i in vitro oslobađanje lijeka nakon 1 i 10 h. Pronađeno je da Pluronic F 68 u kombinaciji s Pluronic F 127 ima značajan učinak na temperaturu geliranja u rasponu od 33 do $36^{\circ} \mathrm{C}$. S druge strane, Gelrite ima povoljan učinak na jačinu bioadhezije, čvrstoću gela i oslobađanje lijeka. Razvijen je kvadratni matematički model pomoću kojeg se može predvidjeti temperatura geliranja, čvrstoća gela, jačina bioadhezije i oslobađanje ljekovite tvari.

Ključne riječi: moksifloksacin hidroklorid, in situ geliranje, oftalmička isporuka lijeka, mukoadhezivni polimeri, $3^{2}$ potpuno faktorijsko dizajniranje

Department of Pharmaceutics, K. B. Institute of Pharmaceutical Education and Research, Gandhinagar 382023-Gujarat, India

Department of Pharmaceutics, Shri Sarvajanik Pharmacy College, 384001-Mehsana, India

Director \& Professor, C. U. Shah College of Pharmacy and Research, Wadhwan, 363030-Gujarat, India 